\title{
Uji Mikrobiologis Salmonella, Water Activity dan Total Bakteri Multinutrien Blok dari Cangkang Kerang dan Cangkang Telur sebagai Sumber Mineral
}

\author{
Microbiological Test of Salmonella, Water Activity and Bacterial Count on Multinutrient \\ Block from Cockle and Egg Shells as Mineral Sources
}

\section{E. Wulandari, B. I. M. Tampoebolon, Widiyanto, dan R. I. Pujaningsih}

Departemen Peternakan, Fakultas Peternakan dan Pertanian, Universitas Diponegoro, Kompl. drh. R. Soejono Koesoemowardojo, Tembalang Semarang Kode Pos 50275

Corresponding Author: endahwulandari202@gmail.com

\begin{abstract}
This research aimed to determine and study the effect of differences in the addition of shell types in multinutrient block (MNB) to Salmonella, water activity and bacterial count. The material used were MNB consisting of cockle shells, egg shells, corn forage, molasses, bentonite, urea and salt, medium nutrient agar (NA) as a medium to calculate bacterial count and MacConkey media for Salmonella. This research used a completely random design with 4 treatments and 4 replications. $\mathrm{T}_{0}=\mathrm{MNB}$ without cockle and egg shells., $\mathrm{T}_{1}=$ MNB used cockle shells $6 \%$., $\mathrm{T}_{2}=\mathrm{MNB}$ used $6 \%$ egg shell., $\mathrm{T}_{3}=\mathrm{MNB}$ used $3 \%$ cockle shells and $3 \%$ egg shells. The parameters observed were qualitative analysis of Salmonella, water activity and bacterial count. The results showed that there were significant effect $(\mathrm{P}<0.05)$ between of different types of shells on MNB to bacterial count and water activity. Qualitative analysis of Salmonella showed that there was no Salmonella in each treatment. Based on the results of the study, it could be concluded that MNB with salt as the only mineral source having a low Aw value which causes a low bacterial count on MNB.
\end{abstract}

Key words : Multinutrien block, Salmonella, bacterial count, water activity

\begin{abstract}
ABSTRAK
Penelitian ini bertujuan untuk mengetahui dan mengkaji pengaruh perbedaan penambahan jenis cangkang pada multinutrien blok (MNB) terhadap Salmonella, water activity dan total bakteri. Materi yang digunakan pada penelitian ini yaitu MNB yang terdiri dari cangkang kerang, cangkang telur, hijauan jagung, molases, bentonit, urea dan garam, $\mathrm{NaCl} 0,85 \%$, medium nutrient agar (NA)sebagai media untuk menghitung total bakteri dan media MacConkey untuk media Salmonella. Penelitian menggunakan rancangan acak lengkap dengan 4 perlakuan dan 4 ulangan. $\mathrm{T}_{0}=$ MNB tanpa cangkang kerang dan cangkang telur., $\mathrm{T}_{1}=\mathrm{MNB}$ menggunakan cangkang kerang 6\%., $\mathrm{T}_{2}=\mathrm{MNB}$ menggunakan cangkang telur 6\%., $\mathrm{T}_{3}=\mathrm{MNB}$ menggunakan cangkang kerang $3 \%$ dan cangkang telur 3\%. Parameter yang diamati yaitu jumlah kualitatif Salmonella, water activity dan total bakteri. Hasil penelitian menunjukkan bahwa penambahan cangkang kerang dan cangkang telur pada MNB berpengaruh nyata $(\mathrm{P}<0,05)$ terhadap total bakteri dan water activity. Analisis kualitatif Salmonella menunjukkan bahwa tidak terdapat Salmonella pada tiap perlakuan. Berdasarkan hasil penelitian, dapat disimpulkan bahwa MNB dengan garam sebagai satu-satunya sumber mineral memiliki nilai Aw yang rendah sehingga menyebabkan jumlah total bakteri pada MNB rendah.
\end{abstract}

Kata Kunci: Multinutrien block, Salmonella, total bakteri, water activity

\section{PENDAHULUAN}

Pakan merupakan kebutuhan pokok bagi ternak yang digunakan untuk pertumbuhan, produksi dan reproduksi. Ternak membutuhkan pakan berkualitas untuk dapat mengoptimalkan produktivitasnya. Peternak biasanya hanya memberikan pakan berupa hijauan dan konsentrat yang jarang memenuhi semua kebutuhan nutrien ternak terutama mineral.
Kebutuhan mineral bagi ternak kambing seringkali kurang diperhatikan oleh para peternak, padahal mineral memiliki peranan penting dalam semua aspek metabolisme. Kekurangan atau kelebihan salah satu mineral dapat mengakibatkan gangguan dalam metabolisme yang berdampak pada penurunan produksi (Sriagtula, 2008). Penurunan produksi antara lain tercermin pada rendahnya pertambahan bobot badan (PBB). Strategi perbaikan 
nutrien untuk ternak kambing dapat dilakukan dengan melakukan suplementasi nutrien yang mengandung energi, protein dan mineral, salah satunya dapat diberikan dalam bentuk multinutrien blok (MNB).

Multinutrien blok merupakan pakan pelengkap yang diberikan kepada ternak ruminansia dalam bentuk silinder atau balok padat yang mengandung energi, protein, mineral dan vitamin (Garcia dan Restrepo, 1995). Pakan pelengkap ini dapat memberikan tambahan nutrien bagi ternak kambing sehingga dapat meningkatkan konsumsi serta daya cerna. Multinutrien blok terbuat dari beberapa bahan pakan yang dapat mencukupi kebutuhan ternak dengan komposisi molases $50 \%$, serat $20 \%$, urea $10 \%$, semen $5 \%$, kapur $5 \%$, garam $5 \%$ dan tepung tulang $5 \%$.

Molases sering digunakan sebagai bahan pakan sebagai sumber energi, selain itu molases juga berfungsi untuk meningkatkan palatabilitas, aktivitas mikroba rumen, sintesis protein mikroba dan mengurangi tekstur berdebu dalam pakan kering. Urea dapat dimanfaatkan sebagai sumber non protein nitrogen (NPN) sedangkan bentonit digunakan sebagai bahan pengikat yang dapat meningkatkan sifat fisik dengan menurunkan kadar air dan meningkatkan ketahanan benturan.

Pakan sumber mineral dapat berasal dari limbah yang belum termanfaatkan misalnya cangkang kerang dan cangkang telur. Jenis kerang yang dapat digunakan yaitu cangkang kerang darah (Anadara granosa). Kandungan mineral pada cangkang kerang darah yaitu $98 \% \mathrm{CaCO}_{3}, 0,20 \% \mathrm{Mg}$, $0,87 \% \mathrm{Na}, 0,02 \% \mathrm{P}$ dan $0,04 \% \mathrm{~K}$ (Zakaria et al., 2004). Kandungan mineral pada cangkang telur yaitu $90,9 \% \mathrm{CaCO}_{3}, 0,12 \% \mathrm{P}$, $0,15-0,17 \% \mathrm{Na}, 0,37-0,40 \% \mathrm{Mg}, 0,10-$ $0,13 \% \mathrm{~K}$ dan $0,09-0,19 \% \mathrm{~S}$ (Warsy et al., 2016).

Pengolahan limbah cangkang kerang dan cangkang telur dimaksudkan untuk menjamin keamanan pakan tersebut karena dikhawatirkan bahan pakan tersebut mengandung bakteri yang berbahaya apabila dikonsumsi oleh ternak. Hasil penelitian
Chusniati et al. (2009), sebanyak 5,56\% dari 36 sampel telur ayam buras di Kecamatan Sidoarjo positif tercemar Salmonella $s p$. Infeksi Salmonella menyebabkan penyakit salmonellosis yang ditandai dengan diare, hal ini sering dijumpai pada ternak yang masih muda dibandingkan ternak dewasa (Davies, 2001 ., Suwito, 2010). Pembuatan MNB yang tidak aseptis juga dapat berpengaruh terhadap bakteri yang terkandung pada MNB.

Tujuan penelitian yaitu untuk mengetahui dan mengkaji pengaruh perbedaan penambahan jenis cangkang pada multinutrien blok (MNB) terhadap Salmonella sp., water activity dan total bakteri. Manfaat penelitian yaitu memperoleh formulasi MNB yang baik ditinjau dari kandungan Salmonella sp., water activity dan total bakteri. Hipotesis yang digunakan yaitu formulasi ransum dengan penambahan MNB yang menggunakan cangkang kerang dan cangkang telur memiliki kualitas yang baik ditinjau dari kandungan Salmonella, water activity dan total bakteri.

\section{MATERI DAN METODE}

Penelitian dilaksanakan pada bulan Juli sampai Agustus 2018. Lokasi penelitian yaitu di Kandang Penelitian Kambing Desa Mrunten Wetan, Kecamatan Ungaran Barat dan Laboratorium Teknologi Pakan Fakultas Peternakan dan Pertanian Universitas Diponegoro, Semarang.

\section{Materi}

Materi yang digunakan pada penelitian ini yaitu MNB yang terdiri dari cangkang kerang, cangkang telur, hijauan jagung, molases, bentonit, urea dan garam, $\mathrm{NaCl} 0,85 \%$, media nutrient agar (NA). Untuk menghitung total bakteri dan media MacConkey untuk media Salmonella sp. serta media biokimia.

\section{Tahap Pembuatan Multinutrien Blok}

Pembuatan MNB merujuk pada peneletian (Garcia dan Restrepo, 1995). Pembuatan MNB diawali dengan pencucian pada cangkang kerang dan cangkang telur 
yang didapat dari lingkungan Universitas Diponegoro. Cangkang kerang dan cangkang telur dikeringkan di bawah sinar matahari dan ditumbuk agar memudahkan dalam proses penggilingan. Hijauan jagung di potong menjadi ukuran yang lebih kecil menggunakan chopper untuk memudahkan dalam proses penggilingan. Hijauan jagung, cangkang kerang dan cangkang telur kemudian dihaluskan menggunakan grinder. Penimbangan bahan-bahan penyusun MNB dilakukan sesuai komposisi yang dapat dilihat pada Tabel 1.

Molases dipanaskan selama 10 menit dengan suhu $40-50^{\circ} \mathrm{C}$ dan diaduk terus menerus. Bahan penyusun MNB dicampur di dalam ember. Pencampuran bahan dilakukan dengan menuangkan bahan dengan komposisi terbesar kemudian berlanjut diikuti bahan dengan komposisi paling rendah. Bahan dicampur hingga homogen, lalu molases dituangkan dan dicampur dengan bahan lainnya. Proses pencetakan MNB dilakukan menggunakan pipa dengan ukuran yang sama. Multinutrien blok disimpan diruangan terbuka di bawah naungan.

Tabel 1. Komposisi MNB Masing-masing Perlakuan

\begin{tabular}{lcccc}
\hline Bahan Pakan & \multicolumn{4}{c}{ Perlakuan } \\
& $\mathrm{T}_{0}$ & $\mathrm{~T}_{1}$ & $\mathrm{~T}_{2}$ & $\mathrm{~T}_{3}$ \\
\hline Molases & $-----------(\%)$ & ----------- \\
Hijauan jagung & 50 & 50 & 50 & 50 \\
Cangkang kerang & 36 & 30 & 30 & 30 \\
Cangkang telur & - & 6 & - & 3 \\
Garam & - & - & 6 & 3 \\
Urea & 4 & 3 & 3 & 3 \\
Bentonit & 7 & 4 & 4 & 4 \\
Jumlah & 100 & 100 & 100 & 100 \\
\hline
\end{tabular}

Keterangan : $\mathrm{T}_{0}$ : MNB tanpa pemberian cangkang kerang dan cangkang telur., T1 : MNB menggunakan cangkang kerang 6\%., T2 : MNB menggunakan cangkang telur 6\%., T3 : MNB menggunakan cangkang kerang 3\% dan cangkang telur $3 \%$

\section{Tahap Analisis}

Analisis total bakteri dilaksanakan berdasarkan (Fardiaz, 1993) dengan metode tuang (pour plate). Tabung reaksi steril disiapkan sebanyak 4 buah dan diberi tanda $10^{-1}, 10^{-2}, 10^{-3}, 10^{-4}$. Masing-masing tabung diisi dengan $\mathrm{NaCl}$ 0,85\% steril sebanyak 9 ml. Multinutrien blok diambil $1 \mathrm{~g}$, lalu dimasukkan ke dalam tabung $10^{-1}$ dan dihomogenkan. Sebanyak $1 \mathrm{ml}$ dari tabung $10^{-1}$ diambil dan dimasukkan ke tabung $10^{-2}$ lalu dihomogenkan. Proses pengenceran dilakukan sampai dengan tabung $10^{-4}$. Masing-masing pengenceran diambil $1 \mathrm{ml}$ kemudian dituangkan ke dalam cawan petri steril dan diberi tanda $10^{-1}, 10^{-2}, 10^{-3}, 10^{-4}$. Sebanyak $1 \mathrm{ml} \mathrm{NaCl} 0,85 \%$ dimasukkan ke dalam cawan petri untuk blanko. Media NA cair disiapkan dan dituangkan pada masingmasing cawan petri sebanyak $20 \mathrm{ml}$ kemudian dihomogenkan dan ditunggu hingga membeku. Media diinkubasi dengan suhu $37^{\circ} \mathrm{C}$ selama 18 - 24 jam setelah itu dihitung jumlah koloni yang tumbuh pada media. Perhitungan jumlah koloni berdasarkan rumus: Jumlah bakteri $=$ Jumlah koloni $\mathrm{x}$ Volume yang ditanam $\mathrm{x}$ Pengenceran.

Analisis kualitatif Salmonella dilaksanakan berdasarkan (Cappuccino dan Sherman, 1987). Sampel yang sudah peletncerkan $10^{-1}$ diinokulasikan pada media MacConkey menggunakan ose secara aseptis dan diinkubasikan pada inkubator pada suhu $37^{\circ} \mathrm{C}$ selama $18-24$ jam. Uji biokimia dilakukan dengan pengamatan koloni yang tumbuh pada media MacConkey, dipilih koloni yang berwarna merah kemudian diinokulasikan pada media uji biokimia. Media uji biokimia meliputi indol, motil, glukosa, laktosa, maltosa, sakarosa, manitol, urea, Triple Sugar Iron Agar (TSIA), Voges Proskauer (VP), Methyl Red (MR) dan Simon Citrate. Media uji biokimia kemudian diinkubasikan pada suhu $37^{\circ} \mathrm{C}$ selama $18-$ 24 jam.

Perhitungan Water activity berdasarkan (Saputra et al., 2014) diukur menggunakan Aw meter. Perangkat ini terdiri dari sensor pembaca, sample holder dan disposable sample container. Perangkat Awmeter dikondisikan pada ruangan pengukuran selama kurang lebih 2 jam. Aktivitas air sampel diukur dengan menempatkan sampel dalam sampel container dan mengkondisikannya selama 30 
- 60 menit. Sensor kemudian dikontakkan dengan sampel dalam container dalam keadaan terbuka. Nilai aktivitas air akan terbaca pada panel. Pengukuran nilai aktivitas air dilakukan sebanyak dua kali untuk tiap sampel.

\section{Analisis Data}

Penelitian menggunakan rancangan acak lengkap (RAL) dengan 4 perlakuan dan 4 ulangan. Perlakuan yang diberikan yaitu :

$\mathrm{T}_{0}=$ MNB tanpa pemberian cangkang kerang dan cangkang telur

$\mathrm{T}_{1}=\mathrm{MNB}$ menggunakan cangkang kerang $6 \%$

$\mathrm{T}_{2}=\mathrm{MNB}$ menggunakan cangkang telur $6 \%$

$\mathrm{T}_{3}=$ MNB menggunakan cangkang kerang $3 \%$ dan cangkang telur $3 \%$

Semua data yang diperoleh kemudian diolah dan dianalisa menggunakan uji ANOVA, jika diperoleh hasil yang signifikan maka dilakukan Uji Jarak Berganda Duncan.

\section{HASIL DAN PEMBAHASAN}

\section{Analisis Kualitatif Salmonella sp.}

Hasil analisis kualitatif Salmonella sp. pada Multinutrien blok dengan penambahan cangkang kerang dan cangkang telur dapat dilihat pada Tabel 2. Berdasarkan hasil analisis kualitatif Salmonella sp. pada Tabel 2, MNB masing-masing perlakuan tidak mengandung bakteri Salmonella sp. Hal inimenunjukkan bahwa MNB aman untuk diberikan kepada ternak karena sesuai dengan standar yang ditetapkan. Menurut
Standar Nasional Indonesia (2009), batas maksimum cemaran Salmonella sp. pada telur segar yaitu negatif per $25 \mathrm{~g}$ sampel. Bakteri Salmonella sp. merupakan bakteri yang bersifat patogen bagi manusia maupun ternak. Davies (2001) yang dikutip oleh Suwito (2010) menyatakan bahwa infeksi Salmonella menyebabkan penyakit salmonellosis yang ditandai dengan diare. Hal ini sering dijumpai pada ternak yang masih muda dibandingkan ternak dewasa. Oleh karena itu perlu adanya upaya yang dilakukan untuk mencegah kontaminasi Salmonella sp. dalam pakan.

Upaya yang dapat dilakukan untuk mencegah kontaminasi Salmonella sp. pada pakan yaitu dengan melakukan pemanasan saat proses pengolahan. Menurut Suwito (2010), agar pakan bebas dari kontaminasi Salmonella sp. dapat dilakukan dengan memilih bahan baku yang tidak terkontaminasi Salmonella sp., memberikan perlakuan panas saat pengolahan dan mencegah kontaminasi ulang pada pakan yang sudah jadi. Proses pengolahan cangkang kerang dan cangkang telur dilakukan dengan pencucian, pengeringan dan penggilingan. Proses pengeringan dapat menghambat pertumbuhan bakteri karena dapat menurunkan kadar air. Bakteri tumbuh pada nilai Aw 0,9 sedangkan pada penelitian, nilai Aw yaitu antara 0,5 - 0,6 sehingga bakteri tidak tumbuh pada MNB. Retnani et al. (2011) menyatakan bahwa bakteri tumbuh pada nilai Aw 0,9, kapang 0,6 - 0,7 dan khamir $0,8-0,9$.

Tabel 2. Analisis Kualitatif Salmonella sp. pada MNB yang diberi Perlakuan dengan Formulasi yang Berbeda

\begin{tabular}{ccccc}
\hline \multirow{2}{*}{ Ulangan } & \multicolumn{5}{c}{ Perlakuan } \\
\cline { 2 - 5 } & $\mathrm{T}_{0}$ & $\mathrm{~T}_{1}$ & $\mathrm{~T}_{2}$ & $\mathrm{~T}_{3}$ \\
\hline $\mathrm{U}_{1}$ & Negatif & Negatif & Negatif & Negatif \\
$\mathrm{U}_{2}$ & Negatif & Negatif & Negatif & Negatif \\
$\mathrm{U}_{3}$ & Negatif & Negatif & Negatif & Negatif \\
$\mathrm{U}_{4}$ & Negatif & Negatif & Negatif & Negatif \\
\hline
\end{tabular}

\section{Water Activity Multinutrien Blok}

Hasil analisis water activitypada multinutrien blok dengan penambahan cangkang kerang dan cangkang telur dapat dilihat pada Tabel 3 . 
Tabel 3. Water Activity MNB yang diberi perlakuan dengan formulasi yang berbeda

\begin{tabular}{ccccc}
\hline \multirow{2}{*}{ Ulangan } & \multicolumn{4}{c}{ Perlakuan } \\
\cline { 2 - 5 } & $\mathrm{T}_{0}$ & $\mathrm{~T}_{1}$ & $\mathrm{~T}_{2}$ & $\mathrm{~T}_{3}$ \\
\hline $\mathrm{U}_{1}$ & 0,5450 & 0,6065 & 0,6240 & 0,6050 \\
$\mathrm{U}_{2}$ & 0,5130 & 0,6010 & 0,6115 & 0,6080 \\
$\mathrm{U}_{3}$ & 0,5125 & 0,5960 & 0,6080 & 0,6065 \\
$\mathrm{U}_{4}$ & 0,5185 & 0,6005 & 0,6040 & 0,6075 \\
Rataan & $0,5223^{\mathrm{b}}$ & $0,6010^{\mathrm{a}}$ & $0,6119^{\mathrm{a}}$ & $0,6068^{\mathrm{a}}$ \\
${ }^{\mathrm{ab}}$ superskrip yang berbeda pada baris yang sama menunjukkan perbedaan yang nyata $(\mathrm{P}<0,05)$
\end{tabular}

Hasil analisis ragam menunjukkan bahwa penggunaan cangkang kerang dan cangkang telur pada MNB berpengaruh nyata $(\mathrm{P}<0,05)$ terhadap nilai Aw. Hasil uji berganda Duncan menunjukkan bahwa MNB yang tidak diberi penambahan cangkang memiliki nilai Aw terendah dibandingkan dengan MNB yang ditambahkan dengan cangkang. Nilai Aw yang tinggi pada penambahan cangkang dipengaruhi oleh nilai Aw dari masing-masing cangkang. Cangkang kerang memiliki nilai Aw 0,4975 sedangkan nilai Aw pada cangkang telur yaitu 0,5145, sehingga nilai Aw pada MNB yang diberi penambahan cangkang lebih besar daripada MNB yang tidak diberi cangkang. Multinutrien blok pada $\mathrm{T}_{0}$ dengan garam sebagai satu-satunya sumber mineral memiliki nilai Aw yang rendah karena garam bersifat higroskopis sehingga mampu menarik air dari MNB. Menurut Aisyah et al. (2013), garam bersifat higroskopis yang mudah menyerap air. Desniar et al. (2009) menyatakan bahwa garam mampu menarik air dari bahan pakan sehingga dapat menurunkan nilai Aw.

Aktivitas air merupakan air bebas yang mendukung pertumbuhan mikroba. Nilai Aw berhubungan dengan kualitas pakan. Menurut Leviana dan Paramita
(2017), tinggi rendahnya nilai aktivitas air akan mempengaruhi waktu simpan dan kualitas pakan. Semakin tinggi nilai Aw maka semakin kecil daya tahan bahan akibat tumbuhnya mikroorganisme. Berdasarkan hasil penelitian menunjukkan bahwa nilai Aw dalam kisaran $0,5-0,6$, pada kisaran tersebut mikroorganisme patogen belum tumbuh. Yatno dan Purwanti (2010) menyatakan bahwa apabila suatu pakan memiliki nilai Aw $0,70-0,75$ pakan dinyatakan tidak aman karena mikroorganisme berbahaya mulai tumbuh dan pakan akan beracun.

\section{Total Bakteri pada Multinutrien Blok}

Hasil uji total bakteri pada multinutrien blok dengan penambahan cangkang kerang dan cangkang telur dapat dilihat pada Tabel 4.

Hasil analisis ragam menunjukkan bahwa penggunaan cangkang kerang dan cangkang telur pada MNB berbeda nyata terhadap kandungan total bakteri. Hasil rataan menunjukkan bahwa $\mathrm{T}_{0}$ memiliki total bakteri paling rendah yaitu $5,4 \times 10^{4} \mathrm{cfu} / \mathrm{g}$, sedangkan total bakteri paling tinggi yaitu pada $\mathrm{T}_{2}$ sebesar $1,85 \times 10^{5} \mathrm{cfu} / \mathrm{g}$. Hal ini menunjukkan bahwa cangkang telur sangat mudah terkontaminasi oleh bakteri.

Tabel 4. Total bakteri MNB yang diberi perlakuan dengan formulasi yang berbeda

\begin{tabular}{|c|c|c|c|c|}
\hline \multirow{2}{*}{ Ulangan } & \multicolumn{4}{|c|}{ Perlakuan } \\
\hline & $\mathrm{T}_{0}$ & $\mathrm{~T}_{1}$ & $\mathrm{~T}_{2}$ & $T_{3}$ \\
\hline $\mathrm{U}_{1}$ & $5,0 \times 10^{4}$ & $9,3 \times 10^{4}$ & $2,03 \times 10^{5}$ & $1,47 \times 10^{5}$ \\
\hline $\mathrm{U}_{2}$ & $5,5 \times 10^{4}$ & $1,03 \times 10^{5}$ & $2,03 \times 10^{5}$ & $1,39 \times 10^{5}$ \\
\hline $\mathrm{U}_{3}$ & $4,5 \times 10^{4}$ & $8,1 \times 10^{4}$ & $1,70 \times 10^{5}$ & $1,30 \times 10^{5}$ \\
\hline $\mathrm{U}_{4}$ & $6,6 \times 10^{4}$ & $9,5 \times 10^{4}$ & $1,64 \times 10^{5}$ & $1,09 \times 10^{5}$ \\
\hline Rataan & $5,4 \times 10^{4 d}$ & $9,3 \times 10^{4 \mathrm{c}}$ & $1,85 \times 10^{5 \mathrm{a}}$ & $1,31 \times 10^{5 b}$ \\
\hline
\end{tabular}


Jumlah cemaran bakteri pada cangkang telur yaitu $1,20 \times 10^{5} \mathrm{cfu} / \mathrm{g}$, sedangkan menurut penelitian Pasaribu et al. (2017), cangkang telur memiliki kontaminasi bakteri rata-rata sebesar $1,0 \times 10^{5}-1,2 \times 10^{5}$ $\mathrm{cfu} / \mathrm{g}$. Telur merupakan produk peternakan yang mudah terkontaminasi oleh mikroba sehingga menimbulkan kerusakan fisik serta menyebabkan penurunan kualitas pada telur. Menurut Pasaribu et al. (2017), cemaran mikroba pada telur dapat terjadi melalui transovari ketika telur masih berada di ovarium, transoviduk terjadi melalui membran vitelin atau albumin saat telur melalui oviduk dan melalui cangkang telur terjadi saat telur keluar melalui kloaka. Cemaran mikroba akan semakin bertambah ketika telur berada pada lingkungan yang sudah tercemar oleh mikroorganisme. Menurut Pui et al. (2011), jumlah cemaran mikroba di cangkang telur bervariasi mulai dari sejumlah ratusan hingga jutaan mikroba pada setiap cangkangnya.

Faktor yang mempengaruhi pertumbuhan bakteri ialah faktor lingkungan meliputi $\mathrm{pH}$, suhu dan kontaminasi saat preparasi sampel, selain itu dipengaruhi pula oleh kandungan nutrisi pada pakan yang dapat berfungsi sebagai sumber nutrisi untuk pertumbuhan bakteri. Nilai $\mathrm{pH}$ pada MNB yaitu 7,01 - 7,48 dan merupakan kisaran $\mathrm{pH}$ optimum untuk pertumbuhan bakteri. Menurut Suriani et al. (2013), bakteri memerlukan $\mathrm{pH}$ optimum yaitu $6,5-7,5$ untuh tumbuh optimal, nilai $\mathrm{pH}$ minimum dan maksimum untuk pertumbuhan bakteri yaitu 4 dan 9 . Nilai total bakteri yang berbeda antar perlakuan didukung oleh adanya nilai Aw yang ditampilkan pada Tabel 3, nilai Aw pada MNB dengan penambahan cangkang kerang dan cangkang telur lebih tinggi daripada MNB tanpa penambahan cangkang sehingga total bakteri pada penambahan cangkang lebih tinggi daripada MNB tanpa cangkang. Leviana dan Paramita (2017) menyatakan bahwa tinggi rendahnya nilai aktivitas air akan mempengaruhi waktu simpan dan kualitas pakan, semakin tinggi nilai Aw maka semakin kecil daya tahan bahan akibat tumbuhnya mikroorganisme. Semakin tinggi nilai Aw pada pakan, maka kemungkinan tumbuhnya mikroorganisme akan semakin tinggi pula.

\section{KESIMPULAN}

Multinutrien blok dengan garam sebagai satu-satunya sumber mineral memiliki nilai Aw yang rendah sehingga menyebabkan jumlah total bakteri pada MNB juga rendah. Penggunaan cangkang kerang dan cangkang telur sebagai sumber mineral pada MNB hendaknya dilakukan melalui perlakuan tambahan yang dapat menurunkan total bakteri.

\section{DAFTAR PUSTAKA}

Aisyah, S., M. Effendy dan H. Triajie. 2013. Kandungan $\mathrm{NaCl}$ dan $\mathrm{H}_{2} \mathrm{O}$ Garam Rakyat pada Media Penyimpanan Berbeda. Seminar Nasional Menggagas Kebangkitan Komoditas Unggulan Lokal Pertanian dan Kelautan. Madura, 11 Juni 2013. Fakultas Pertanian Universitas Trunojoyo Madura. Hal: 680 - 689 .

Cappuccino, J. G dan N. Sherman. 1987. Microbiology : A Laboratory Manual. The Benjamin Cummings Publishing Company. Inc. California.

Chusniati, S., R.N. Budiono dan R. Kurnijasanti. 2009. Deteksi Salmonella sp pada telur ayam buras yang dijual sebagai campuran jamu di Kecamatan Sidoarjo. J. of Poultry Disease. 2 (2): 20-23.

Davies, R. 2001. Salmonella typhimurium DT104: has it had its day? Dalam : Suwito, W. 2010. Monitoring Salmonella $s p$ dan Escherichia coli dalam bahan pakan ternak. Buletin Peternakan. 34 (3): $165-168$.

Desniar, D. Poernomo dan W. Wijatur. 2009. Pengaruh konsentrasi garam pada peda ikan kembung (Rastrelliger sp.) dengan fermentasi spontan. Jurnal Pengolahan Hasil Perikanan Indonesia. 12 (1): 73-87.

Fardiaz, S. 1993. Analisis Mikrobiologi Pangan. Raja Grafindo Persada, Jakarta. 
Garcia, L. O dan J. I. R. Restrepo, 1995. Multinutrient Block Handbook (FAO Better Farming Series no. 45). Food and Agriculture Organization of United Nation, Rome.

Leviana, W dan V. Paramita. 2017. Pengaruh suhu terhadap kadar air dan aktivitas air dalam bahan pada kunyit (Curcuma longa) dengan alat pengering electrical oven. METANA. 13:37-44.

Pasaribu, N., Rastina, T. R. Ferasyi, Nurliana, Darniati dan Erina. 2017. Jumlah cemaran mikroba pada telur ayam ras yang dijual di swalayan daerah Darussalam Kecamatan Syiah Kuala Kota Banda Aceh. JIMVET. 1:94-100.

Retnani, Y., L. Herawati dan S. Khusniati. 2011. Uji sifat fisik ransum broiler starter bentuk crumble berperekat tepung tapioka, bentonit dan onggok. JITP. 1:8897.

Saputra, G. A., W. Sarengat dan S. B. M. Abduh. 2014. Aktivitas air, total bakteri dan drip loss daging itik setelah mengalami scalding dengan malam batik. Animal Agricultural Journal. 3:34-40.

Sriagtula, R. 2008. Pengaruh penambahan mineral $\mathrm{Ca}, \mathrm{P}, \mathrm{Mg}$ dan $\mathrm{S}$ dalam ransum terhadap status mineral pada kambing kacang. Jurnal Peternakan. 5:53-60.
Standar Nasional Indonesia. 2009. Batas Maksimum Cemaran Mikroba dalam Pangan. No. 7388-2009. Badan Standarisasi Nasional, Jakarta.

Suriani, S., Soemarno dan Suharjono. 2013. Pengaruh suhu dan $\mathrm{pH}$ terhadap laju pertumbuhan lima isolat bakteri anggota genus pseudomonas yang diisolasi dari ekosistem sungai tercemar deterjen di sekitar kampus Universitas Brawijaya. JPAI. 3:59-62.

Suwito, W. 2010. Monitoring Salmonella sp. dan Escherichia coli dalam bahan pakan ternak. Buletin Peternakan. 34:165-168.

Warsy, S. Chadijah dan W. Rustiah. 2016. Optimalisasi kalsium karbonat dari cangkang telur untuk produksi pasta komposit. Al-Kimia. 4:86-97.

Yatno dan S. Purwanti. 2010. Pengaruh steaming dan lama penyimpanan terhadap sifat fisik pakan burung perkutut. JITP. 1:1927.

Zakaria, Z. A. B., N. Zakaria dan Z. Kasim. 2004. Mineral composition of the cockle (Anadara granosa) shells, hard clamp (Meretrix meretrix) shells and corais (Porites spp.): a comparative study. Journal of Animal and Veterinary Advances. 3:445-447. 